\title{
Role of Fascial Connectivity in Musculoskeletal Dysfunctions: A Narrative Review
}

\author{
MS. Ajimsha, MPT, PhD, DO, MBA*; Pramod D Shenoy MPT; Neeraj Gampawar MPT \\ Department of Physiotherapy, Hamad Medical Corporation, Doha, Qatar \\ *Corresponding author: Ph; (+974)55021106: Email: ajimshaw.ms@gmail.com (ORCID ID: 0000-0003-4182-9838)
}

\begin{abstract}
:
Introduction: Musculoskeletal dysfunctions happen to be the most common reason for referral to physiotherapy and manual therapy services. Therapists may use several articular and/or soft tissue concepts/approaches to evaluate and treat such dysfunctions that may include integration of myofascial system. Despite the research in this area spanning more than three decades, the role played by fascia has not received its duly deserved attention, owing to the lack of definitive research evidence. The concept of 'fascial connectivity' evolved two decades ago from a simple anatomical hypothesis called 'myofascial meridians'. Since then it has been widely researched, as conceptually it makes more sense for functional movements than 'single-muscle' theory. Researchers have been exploring its existence and role in musculoskeletal dysfunctions and clinicians continue to practice based on anecdotal evidence. This narrative review attempts to gather available evidence, in order to support and facilitate further research that can enhance evidence based practice in this field. Methods: A search of most major databases was conducted with relevant keywords that yielded 272 articles as of December 2019. Thirty five articles were included for final review with level of evidence ranging from $3 \mathrm{~b}$ to $2 \mathrm{a}$ (as per Center of Evidence Based Medicine's scoring). Results: Findings from cadaveric, animal and human studies supports the claim of fascial connectivity to neighboring structures in the course of specific muscle-fascia chains that may have significant clinical implications. Current research (level 2) supports the existence of certain myofascial connections and their potential role in the manifestation of musculoskeletal dysfunctions and their treatment. Conclusion: Although these reviews and trials yield positive evidence for the objective reality/existence of fascial connectivity and continuity, several aspects need further exploration and in-depth analysis, which could not be evidenced entirely in this review. Manual and physical therapists may utilize the concept of fascial connectivity as a convincing justification to deal with clinical problems, but need to remain vigilant that functional implications are still being investigated.
\end{abstract}

Keywords: Fascia; fascial connectivity, myofascial meridians; myofascial chains

\section{Introduction}

Musculoskeletal pain and dysfunction are among the main reasons behind visits to physicians and manual therapists; it is also the most frequent cause of long-term chronic pain affecting countless individuals around the world (Woolf \& Pfleger 2003). Without appropriate management, chronic pain may impact several aspects of an individual's health, including physical, psychological, and social well-being, while also creating a tremendous economic and workplace burden. As the prevalence of musculoskeletal pain is expected to increase with a sedentary population having longevity (Woolf \& Pfleger 2003), it calls for more preponderant effort in the development and evaluation of incipient ways of managing these patients.

Manual therapists, use several different schools of thought in dealing with their patients. Some therapists use articular techniques such as that of Maitland's while others use soft tissue techniques such as muscle energy techniques, myofascial release or myofascial manipulation etc. to name but a few. Several researchers find the role of the fascia of interest and utmost significance in musculoskeletal disorders, owing to its potential to influence muscular activity. Research from the past decade has been able to point towards the part played by fascia in numerous musculoskeletal dysfunctions as the skeletal muscles throughout the body are indirectly linked to each other by fascial tissue forming a network with some specific patterns (Luomala, \& Pihlman, 2016; Myers T.W. 2009; Wilke et al., 2016a). These conceptual patterns were later named 'myofascial meridians', as a means to better understand the mapping of the fascial system (Myers T.W. (2009).

Traditionally, researchers studied human movement through a reductionist lens which disintegrates and examines the movements in isolation. The reductionism approach does not identify the complexities intertwined and the diverse dynamics found within complex systems such as human movement. According to Dischiavi et al (2018), human movement may be better understood through holism. This concept can guide 
someone who is attempting to understand the fascia and its intricate system, in order to appreciate its complexity within an apparently simple design. Fascia can be simply defined as a network of fibrous tissue pervading the entire body, which surrounds, supports, suspends, protects, connects and divides muscular, skeletal and visceral components of an organism (Kumka\& Bonar 2012). Apart from lubricating the fibers it also gives nourishment to the whole body (Still 1910). It is said to manage the balance between tension and compression around the organs, joints and muscles, and hence considered as a "tensegrity" or tensional integrity structure (Chen et al., 2016). Depending on its location fascia in general displays marked differences concerning thickness, amount of elastic fibers (Stecco et al., 2009) and adherence and expansions to the surrounding soft tissues including muscles (Stecco et al., 2009). Additionally, the amount of associating fibers is not constant and shows extensive dissimilarity for different transitions (Snow et al., 1995; Stecco et al., 2013)). This holds specific essentialness as the structures connecting the muscular parts of the meridians envelop tendinous, aponeurotic and ligamentous tissue as well as the deep fascia.

It is a known fact that fascia is capable of modifying its tensional situation in response to the stress applied to it (Bordoni, \& Simonelli, 2018. Wilke et al., 2017b;) and it is believed that the strain transmission might occur along certain specific pathways as a response to changing muscle activity (Norton-Old et al. 2013; Krause et al., 2016). Through 'mechanotransduction' (conversion of physical forces into intracellular biochemical responses), these forces may be transmitted at a cellular level, altering gene expression of fibroblasts and thereby changing the extracellular matrix composition (Chaitow 2016; Bordoni et al., 2019). Inflammatory mediators may also be secreted by repeated mechanical straining of fibroblasts (Dodd et al., 2006). All of these changes could influence the regular day-to-day functions of force transmission or sliding required for the musculoskeletal system. Such dysfunction could lead to pain or proprioceptive issues, considering the fact that fascia has been shown to be innervated (Tesarz et al., 2011; Schilder et al., 2018).

There are several theories explaining pathophysiological and pathomechanical processes that follow after myofascial tissue trauma or overuse, extending from cellular (viscoelasticity, piezoelectricity, tensegrity etc.) to global level (force transmission, sliding, fluid dynamics, hysteresis, innervation, sensitization etc.); however, a discussion on this is beyond the scope of this review. The ultimate result of the altered myofascial tissue is restricted fascia, resulting in altered lines of force with muscle contraction (Stecco et al., 2013; Meltzer et al., 2010). Muscles of the body don't operate as independent units; instead, they are considered as a part of a tensegrity-like myofascial network that spans throughout the body, with fascia being the linking component (Wilke et al., 2016b). As time goes by, these biomechanical changes could lead to reduced strength, incoordination, (Ercole et al., 2010; Stecco et al., 2013), pain or proprioceptive dysfunction (Tesarz et al., 2011). Thus, it may be argued that the treatment of disorders affecting the musculoskeletal system may need to be focused on this fascial network (Kwong, \& Findley 2014). The recent increase in research carried out in this field has made treatment targeting the fascia to be increasingly popular in the management of musculoskeletal disorders (Ajimsha 2018).

Although this concept has strong physiologic and histologic support to justify its use by clinicians, it lacks research based evidence for clinical practice. Therefore, this narrative review will outline the historical development of the fascial connectivity concept, and gather evidence regarding its role in musculoskeletal dysfunctions. The main objective of the review was to investigate how several researchers studied this concept to identify/justify the fascial connectivity, its functioning and clinical effectiveness, all of which can form the basis for future research and clinical practice.

For a better understanding of the basis of this concept of connectivity (eg:- myofascial meridians), one needs to know the circumstances that led to its synthesis. The following section gives this information in brief before we proceed to explain the methodology and key findings of this review.

\section{The Myofascial Meridian Concept}

'Myofascial meridian' was a term coined in 1997 by Tom Myers, a prominent anatomist and body-worker. He developed it as a means of expressing to his students the role of the fascial system as it relates to human structure and function. According to this concept, fascia can be viewed as being organized in the body in specific patterns/lines of pull or series of myofascial tissue that disperse strain, facilitate movement, and provide stability throughout the structures of the body (Tozzi 2015). This theory aided practitioners to explore how two or more distant or remote structures in the body influence one another.

In his early years, Tom inspired by his mentor Ida Rolf, developed a game 'anatomy trains' in 1990 to teach his students fascial anatomy at Rolfing institute. The basic idea was to string the muscles together through the fascia, contrary to the then belief of 'single-muscle theory'. Single-muscle theory failed to reason how functional human movement can be performed by a single muscle and provide a holistic perspective. For example, it is highly unlikely that a biceps brachii muscle can perform its function in the most efficient manner in the absence of its antagonists, fixators and synergists. Therefore, this theory failed to answer several important questions relating to functional movement patterns. 
With several years of work in this field, these strings or lines became more apparent to Myers who then started applying this concept on his clients. This later became known as 'myofascial meridians' or 'myofascial chains'. Based on decades of work, research, and practical application on clients, Myers identified 12 specific meridians throughout the body namely,

- $\quad$ Superficial Back Line (SBL)

- $\quad$ Superficial Front Line (SFL)

- $\quad$ Lateral Line (LL)

- $\quad$ Spiral Line (SL)

- $\quad$ Superficial Front Arm Line (SFAL)

- $\quad$ Deep Back Arm Line (DBAL)

- $\quad$ Deep Front Arm Line (DFAL)

- $\quad$ Superficial Back Arm Line (SBAL)

- $\quad$ Back Functional Line (BFL)

- $\quad$ Front Functional Line (FFL)

- Ipsilateral Functional Line (IFL)

- $\quad$ Deep Front Line (DFL)

This review will explore studies that have researched the existence of all or some of this connectivity, appraise the literature, and verify whether they indeed hold true in the causation and/or treatment of musculoskeletal disorders/dysfunctions.

\section{Figure 1: Study flow diagram}

\section{Methods}

A search was conducted in MEDLINE, CINAHL, Academic Search Premier (ASP), Cochrane library, and PEDro databases with keywords 'fascial connectivity' and 'myofascial meridians or chains' for the period till December 2019. Research published in the English language alone was identified, relevant articles were selected after reviewing the abstract, and saved as full text for further review. No grey literature was included. They were then rated with Centre for Evidence-Based Medicine's (CEBM) level of evidence scale and PEDro scale (for experimental studies) to brief their hierarchy of evidence and methodological quality. Two experienced reviewers completed the review process. Any review and rating discrepancies were solved through verbal discussion and a supplementary review by a third reviewer.

\section{Results}

Of the 272 studies identified in the original search, thirtyfive articles were included for the final review (Figure 1). The key characteristics and findings of the included studies are provided in Table 1.

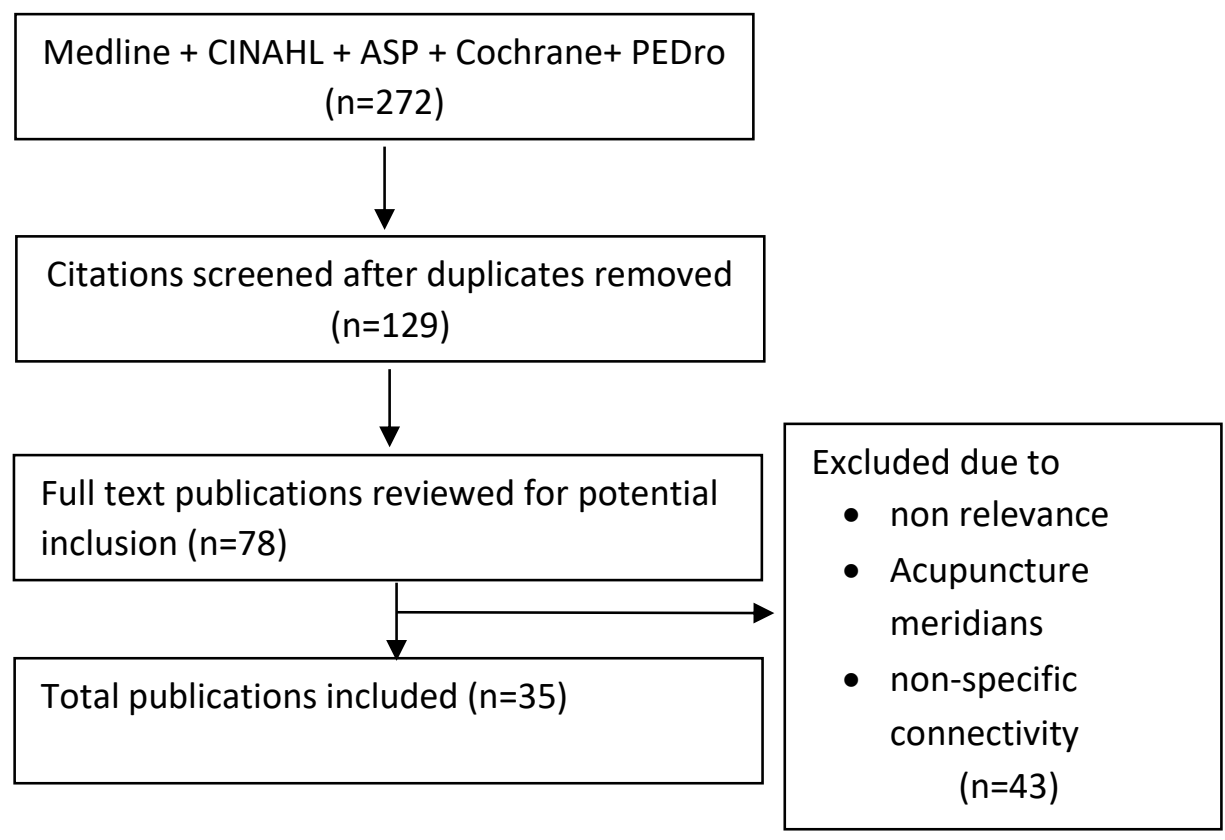




\section{Table 1: key characteristics and findings of the included studies}

\begin{tabular}{|c|c|c|c|c|c|c|c|c|c|}
\hline SI.No. & Year & Author(s) & Objective & $\begin{array}{l}\text { Myofascial } \\
\text { chain tested / } \\
\text { Identified }\end{array}$ & Population & Intervention & Comparison & Outcome measure & $\begin{array}{l}\text { Does the result support } \\
\text { existence of Myofascial } \\
\text { connectivity? }\end{array}$ \\
\hline 1 & 2019 & $\begin{array}{l}\text { Williams, W } \\
\text { and Selkow, } \\
\text { N.M }\end{array}$ & $\begin{array}{l}\text { Remote effect of } \\
\text { self- MFR }\end{array}$ & SBL & $\begin{array}{l}\text { Asymptomatic college } \\
\text { students }\end{array}$ & $\begin{array}{l}\text { self-myofascial } \\
\text { release (SMR) of } \\
\text { the plantar } \\
\text { surface of the } \\
\text { foot in addition to } \\
\text { the hamstring }\end{array}$ & $\begin{array}{l}\text { hamstring foam } \\
\text { rolling, lacrosse ball } \\
\text { on the plantar } \\
\text { surface of the foot, } \\
\text { and a combination } \\
\text { of both }\end{array}$ & $\begin{array}{l}\text { sit-and-reach test - } \\
\text { hamstring flexibility }\end{array}$ & Yes \\
\hline 2 & 2019 & $\begin{array}{l}\text { Wilke, J. and } \\
\text { Krause, F. }\end{array}$ & $\begin{array}{l}\text { review the available } \\
\text { literature } \\
\text { considering the } \\
\text { existence of } \\
\text { myofascial chains in } \\
\text { the shoulder-arm } \\
\text { region }\end{array}$ & $\begin{array}{l}\text { Ventral, } \\
\text { Dorsal and } \\
\text { Lateral arm } \\
\text { chain }\end{array}$ & $\begin{array}{l}\text { anatomical cadaver } \\
\text { studies (publication } \\
\text { between } 1900 \text { and } \\
\text { 2019) that reported } \\
\text { morphological } \\
\text { in-series tissue } \\
\text { continuity between } \\
\text { muscles of } \\
\text { the upper limb and } \\
\text { shoulder }\end{array}$ & Systematic review & systematic review & $\begin{array}{l}\text { QUACS scale for quality } \\
\text { rating }\end{array}$ & Yes \\
\hline 3 & 2019 & Wilke et al. & $\begin{array}{l}\text { examine the age } \\
\text { dependency of } \\
\text { nonlocal exercise } \\
\text { effects following } \\
\text { plantar fascia SMR }\end{array}$ & SBL & Healthy subjects & $\begin{array}{l}\text { plantar foot SMR, } \\
\text { performed in } \\
\text { standing position }\end{array}$ & $\begin{array}{l}\text { different age } \\
\text { groups }\end{array}$ & $\begin{array}{l}\text { sit and reach test - } \\
\text { hamstring flexibility }\end{array}$ & Yes \\
\hline 4 & 2019 & Wang, J & $\begin{array}{l}\text { the effects of } \\
\text { forearm plank } \\
\text { exercise on tone } \\
\text { and stiffness in } \\
\text { the superficial } \\
\text { back line muscle }\end{array}$ & SBL & Healthy subjects & $\begin{array}{l}\text { sling forearm } \\
\text { plank exercises } \\
\text { and mat forearm } \\
\text { plank exercises }\end{array}$ & $\begin{array}{l}\text { two forms of } \\
\text { forearm plank } \\
\text { exercises }\end{array}$ & $\begin{array}{l}\text { muscle tone and } \\
\text { stiffness - upper lumbar } \\
\text { muscles, lower lumbar } \\
\text { muscles, long head of } \\
\text { biceps femoris, and } \\
\text { medial part of } \\
\text { gastrocnemius }\end{array}$ & probably \\
\hline 5 & 2019 & $\begin{array}{l}\text { Sulowska et } \\
\text { al. }\end{array}$ & $\begin{array}{l}\text { evaluate the } \\
\text { influence of plantar } \\
\text { short foot muscles } \\
\text { exercises on the } \\
\text { performance of } \\
\text { lower extremities }\end{array}$ & SBL & long-distance runners & $\begin{array}{l}\text { plantar short foot } \\
\text { muscles exercises }\end{array}$ & $\begin{array}{l}\text { Group } 1 \text { with } \\
\text { neutral foot and } \\
\text { Group } 2 \text { with slight } \\
\text { and increased } \\
\text { pronation based on } \\
\text { Foot Posture Index }\end{array}$ & $\begin{array}{l}\text { The knee flexors and } \\
\text { extensors torque, work, } \\
\text { and power on Isokinetic } \\
\text { Dynamometer and } \\
\text { Running-Based } \\
\text { Anaerobic Sprint Test }\end{array}$ & probably \\
\hline 6 & 2019 & Song et al. & $\begin{array}{l}\text { effects of the } \\
\text { myofascial } \\
\text { meridians release } \\
\text { technique on pain } \\
\text { and postural } \\
\text { control }\end{array}$ & SBL & $\begin{array}{l}\text { college students with } \\
\text { forward head } \\
\text { posture }\end{array}$ & & $\begin{array}{l}\text { the intervention } \\
\text { effects of the } \\
\text { Grastone massage } \\
\text { and the Rollfing } \\
\text { massage }\end{array}$ & $\begin{array}{l}\text { numerical rating scale } \\
\text { of } \\
\text { pain, distance of } \\
\text { forward head } \\
\text { displacement and neck } \\
\text { disabilitv index. }\end{array}$ & Yes \\
\hline
\end{tabular}




\begin{tabular}{|c|c|c|c|c|c|c|c|c|c|}
\hline SI.No. & Year & Author(s) & Objective & $\begin{array}{l}\text { Myofascial } \\
\text { chain tested / } \\
\text { Identified }\end{array}$ & Population & Intervention & Comparison & Outcome measure & $\begin{array}{l}\text { Does the result support } \\
\text { existence of Myofascial } \\
\text { connectivity? }\end{array}$ \\
\hline 7 & 2019 & $\begin{array}{l}\text { (Wilhite C } \\
\text { et al.) } \\
\text { Paloncy et } \\
\text { al. }\end{array}$ & $\begin{array}{l}\text { whether the same } \\
\text { increase in hamstring } \\
\text { mobility within the } \\
\text { superficial backline } \\
\text { function that is } \\
\text { achieved with a } \\
\text { clinician- } \\
\text { administered } \\
\text { suboccipital trigger } \\
\text { point release can also } \\
\text { be obtained through } \\
\text { a patient/self- } \\
\text { administered method }\end{array}$ & SBL & Asymptomatic adults & $\begin{array}{l}\text { suboccipital } \\
\text { trigger point } \\
\text { release }\end{array}$ & $\begin{array}{l}\text { Clinician } \\
\text { administered } \\
\text { versus } \\
\text { patient/self- } \\
\text { administered }\end{array}$ & $\begin{array}{l}\text { hamstring mobility - slide } \\
\text { ruler box sit-and-reach- } \\
\text { test }\end{array}$ & Yes \\
\hline 8 & 2019 & $\begin{array}{l}\text { Fousekis et } \\
\text { al. }\end{array}$ & $\begin{array}{l}\text { investigate the } \\
\text { effects of Ergon }{ }^{\circledast} \\
\text { IASTM applications } \\
\text { on the upper } \\
\text { or lower part of the } \\
\text { SBL on the } \\
\text { hamstring's flexibility }\end{array}$ & SBL & $\begin{array}{l}\text { Aymptomatic } \\
\text { university students } \\
\text { with reduced trunk- } \\
\text { hamstring flexibility }\end{array}$ & $\begin{array}{l}\text { Ergon }{ }^{\circledR} \text { IASTM } \\
\text { Technique } \\
\text { applications in } \\
\text { the } \\
\text { posterior trunk } \\
\text { and thigh }\end{array}$ & $\begin{array}{l}3 \text { groups - Upper } \\
\text { SBL, Lower SBL } \\
\text { and Control }\end{array}$ & $\begin{array}{l}\text { hamstring flexibility - Sit- } \\
\text { and-reach test }\end{array}$ & Yes \\
\hline 9 & 2019 & $\begin{array}{l}\text { Devereux } \\
\text { et al. }\end{array}$ & $\begin{array}{l}\text { the effects of treating } \\
\text { latent myofascial } \\
\text { trigger points } \\
\text { (MTrPs) in the lower } \\
\text { limb kinetic chain } \\
\text { with respect to } \\
\text { performance during } \\
\text { sporting actions }\end{array}$ & $\begin{array}{l}\text { Anterior and } \\
\text { Posterior } \\
\text { muscle chains }\end{array}$ & $\begin{array}{l}\text { Male athletes with } \\
\text { MTrPs }\end{array}$ & Dry Needling & $\begin{array}{l}4 \text { groups - Rectus } \\
\text { femoris only; } \\
\text { medial } \\
\text { Gastrocnemius } \\
\text { only; both } \\
\text { muscles; control } \\
\text { group }\end{array}$ & $\begin{array}{l}\text { squat jumps at } 5 \\
\text { incremental loads and } \\
\text { were recorded using the } \\
\text { My Jump app (iOS) for } \\
\text { jump height, power } \\
\text { output, optimal force, } \\
\text { and optimal velocity }\end{array}$ & May be \\
\hline 10 & 2019 & $\begin{array}{l}\text { Danyschuk, } \\
\text { A. }\end{array}$ & $\begin{array}{l}\text { to study the } \\
\text { biomechanical } \\
\text { properties of myo- } \\
\text { fascial kinematic } \\
\text { chain of the foot-tibia }\end{array}$ & $\begin{array}{l}\text { Lateral and } \\
\text { posterior } \\
\text { chain of foot- } \\
\text { tibia }\end{array}$ & $\begin{array}{l}\text { children } 7-14 \text { years } \\
\text { with } \\
\text { unfixed and clinically } \\
\text { pronounced flat feet }\end{array}$ & $\begin{array}{l}\text { Observational } \\
\text { study }\end{array}$ & $\begin{array}{l}2 \text { groups - flat } \\
\text { feet and } \\
\text { functional } \\
\text { disorders of foot }\end{array}$ & $\begin{array}{l}\text { EMG of lateral (long tibia) } \\
\text { and dorsal (posterior } \\
\text { tibia) of the } \\
\text { myo-fascial kinematic } \\
\text { chains of the right and } \\
\text { left } \\
\text { tibia; Video-computer } \\
\text { analysis was performed } \\
\text { with the help of the } \\
\text { system for determining } \\
\text { the } \\
\text { functional state of the } \\
\text { locomotor system; }\end{array}$ & May be \\
\hline
\end{tabular}




\begin{tabular}{|c|c|c|c|c|c|c|c|c|c|}
\hline SI.No. & Year & Author(s) & Objective & $\begin{array}{l}\text { Myofascial } \\
\text { chain tested / } \\
\text { Identified }\end{array}$ & Population & Intervention & Comparison & Outcome measure & $\begin{array}{l}\text { Does the result support } \\
\text { existence of Myofascial } \\
\text { connectivity? }\end{array}$ \\
\hline 11 & 2019 & $\begin{array}{l}\text { Chakhuttray } \\
\text { et al. }\end{array}$ & $\begin{array}{l}\text { to test immediate } \\
\text { effect of the rubber } \\
\text { hammer on fl } \\
\text { exibility on } \\
\text { thesuperfi cial back } \\
\text { line }\end{array}$ & SBL & $\begin{array}{l}\text { Healthy } \\
\text { subjects }\end{array}$ & $\begin{array}{l}\text { applying rubber hammer on } \\
\text { subjects in prone }\end{array}$ & $\begin{array}{l}2 \text { groups - } \\
\text { Expeerimental } \\
\text { (rubber hammer) } \\
\text { and control }\end{array}$ & $\begin{array}{l}\text { Sit and reach test, } \\
\text { straight leg raising } \\
\text { (SLR) test, and Modifi } \\
\text { ed Schober 'stest } \\
\text { were performed to } \\
\text { detect change of } \\
\text { body fl exibility }\end{array}$ & Yes \\
\hline 12 & 2019 & Burk et al. & $\begin{array}{l}\text { To determine if } \\
\text { remote myofascial } \\
\text { techniques can } \\
\text { effectively increase } \\
\text { the range of motion } \\
\text { at a distant body } \\
\text { segment }\end{array}$ & SBL & $\begin{array}{l}\text { RCTs on } \\
\text { human } \\
\text { subjects }\end{array}$ & $\begin{array}{l}\text { MFR or static stretching to } \\
\text { Caudal / Cephalad muscles of } \\
\text { SBL }\end{array}$ & $\begin{array}{l}\text { remote } \\
\text { interventions to } \\
\text { local treatment or } \\
\text { sham or inactive } \\
\text { controls }\end{array}$ & $\begin{array}{l}\text { Multiple measures } \\
\text { including Cervical } \\
\text { spine ROM and Sit- } \\
\text { and-reach distance; } \\
\text { PEDro scale for study } \\
\text { quality }\end{array}$ & Yes \\
\hline 13 & 2019 & Borg et al. & $\begin{array}{l}\text { whether myofascial } \\
\text { treatment, using a } \\
\text { device generating } \\
\text { deep pulsating } \\
\text { vibrations, can } \\
\text { provide increased } \\
\text { ROM and well-being } \\
\text { of patients with } \\
\text { frozen shoulder (FS) }\end{array}$ & - & $\begin{array}{l}\text { Subjects } \\
\text { with } \\
\text { primary FS }\end{array}$ & $\begin{array}{l}\text { soft and deep massage } \\
\text { treatment usung devices } \\
\text { providing mechanical vibrations } \\
\text { at a variable frequency } \\
\text { between } 400 \text { to } 1200 \\
\text { pulsations per minute in a sine } \\
\text { wave }\end{array}$ & none & $\begin{array}{l}\text { Shoulder ROM and } \\
\text { Quality of sleep }\end{array}$ & probably \\
\hline 14 & 2018 & $\begin{array}{l}\text { Vulfsons et } \\
\text { al. }\end{array}$ & $\begin{array}{l}\text { To examine muscle } \\
\text { activations along the } \\
\text { superficial back line } \\
\text { in LBP patients }\end{array}$ & SBL & $\begin{array}{l}\text { Chronic Low } \\
\text { back pain }\end{array}$ & $\begin{array}{l}\text { muscle activation during } \\
\text { conditions 1-3: passive } \\
\text { movement, active movement } \\
\text { and active movement against } \\
\text { maximum isometric resistance } \\
\text { of the right gastrocnemius } \\
\text { muscle; and conditions 4-5 } \\
\text { neck extension without and } \\
\text { with isometric resistance from } \\
\text { the prone position }\end{array}$ & $\begin{array}{l}\text { Chronic low baack } \\
\text { pain versus healthy } \\
\text { controls }\end{array}$ & $\begin{array}{l}\text { sEMG measurement } \\
\text { of muscle activation } \\
\text { of gastrocnemius, } \\
\text { hamstrings, erector } \\
\text { spine, and upper } \\
\text { trapezius }\end{array}$ & Yes \\
\hline 15 & 2018 & Tijs et al & $\begin{array}{l}\text { to assess whether } \\
\text { myofascial loads } \\
\text { exerted by } \\
\text { neighboring muscles } \\
\text { result in } \\
\text { length changes of } \\
\text { Soleus (SO) muscle } \\
\text { fascicles }\end{array}$ & SBL & $\begin{array}{l}\text { animal } \\
\text { study }\end{array}$ & $\begin{array}{l}\text { the effects of proximal muscle- } \\
\text { tendon unnit length changes of } \\
\text { two-joint gastrocnemius } \\
\text { (GA) and plantaris (PL) muscles } \\
\text { on the fascicle length of the } \\
\text { one-joint SO muscle }\end{array}$ & $\begin{array}{l}\text { measurement in } 2 \\
\text { conditions: within } \\
\text { (1) an intact muscle } \\
\text { compartment } \\
\text { and (2) a disrupted } \\
\text { compartment }\end{array}$ & sonomicrometry & Yes \\
\hline
\end{tabular}




\begin{tabular}{|c|c|c|c|c|c|c|c|c|c|}
\hline SI.No. & Year & Author(s) & Objective & $\begin{array}{l}\text { Myofascial } \\
\text { chain tested / } \\
\text { Identified }\end{array}$ & Population & Intervention & Comparison & Outcome measure & $\begin{array}{l}\text { Does the result support } \\
\text { existence of Myofascial } \\
\text { connectivity? }\end{array}$ \\
\hline 16 & 2018 & Raţă et al. & $\begin{array}{l}\text { track the effects of } \\
\text { stretching on the } \\
\text { electromyographic } \\
\text { activity of muscle } \\
\text { chains }\end{array}$ & $\begin{array}{l}\text { Anterior and } \\
\text { Posterior } \\
\text { muscle chains }\end{array}$ & $\begin{array}{l}\text { Subject with } \\
\text { Haglund's } \\
\text { disease }\end{array}$ & $\begin{array}{l}\text { static stretching } \\
\text { positions }\end{array}$ & Single case study & $\begin{array}{l}\text { visual examination and } \\
\text { surface } \\
\text { electromyography } \\
\text { (maximum volumetric } \\
\text { isometric contraction) }\end{array}$ & Yes \\
\hline 17 & 2018 & $\begin{array}{l}\text { Marizeiro et } \\
\text { al. }\end{array}$ & $\begin{array}{l}\text { immediate effects } \\
\text { of diaphragmatic } \\
\text { myofascial release }\end{array}$ & $\begin{array}{l}\text { Posterior } \\
\text { chain muscle }\end{array}$ & $\begin{array}{l}\text { sedentary } \\
\text { women }\end{array}$ & $\begin{array}{l}\text { diaphragmatic } \\
\text { myofascial release } \\
\text { techniques }\end{array}$ & $\begin{array}{l}\text { Experimental group and } \\
\text { Control (placebo) group }\end{array}$ & $\begin{array}{l}\text { chest wall mobility } \\
\text { using cirtometry; } \\
\text { flexibility, lumbar spine } \\
\text { range of motion, and } \\
\text { respiratory muscle } \\
\text { strength }\end{array}$ & Yes \\
\hline 18 & 2018 & Joshi et al. & $\begin{array}{l}\text { effect of Static } \\
\text { Stretching (SS) of } \\
\text { hamstrings with } \\
\text { remote Myofascial } \\
\text { Release (MFR) and } \\
\text { a combination on } \\
\text { hamstring } \\
\text { flexibility. }\end{array}$ & SBL & $\begin{array}{l}\text { asymptomatic } \\
\text { adults }\end{array}$ & $\begin{array}{l}\text { Static Stretching (SS) of } \\
\text { hamstrings with remote } \\
\text { Myofascial Release } \\
\text { (MFR) (bilateral plantar } \\
\text { fascia and suboccipital } \\
\text { region) and a } \\
\text { combination of SS and } \\
\text { remote MFR on } \\
\text { hamstring flexibility. }\end{array}$ & $\begin{array}{l}3 \text { groups - SS, MFR and } \\
\text { Combination; therapist } \\
\text { administered versus } \\
\text { patient administered }\end{array}$ & $\begin{array}{l}\text { Knee Extension Angle, } \\
\text { and Sit and Reach Test }\end{array}$ & Yes \\
\hline 19 & 2018 & Do et al. & $\begin{array}{l}\text { investigate the } \\
\text { immediate effect of } \\
\text { applying self- } \\
\text { myofascial release } \\
\text { (SMR) to the } \\
\text { plantar fascia using } \\
\text { a foam roller on } \\
\text { hamstring and } \\
\text { lumbar spine } \\
\text { flexibility }\end{array}$ & SBL & $\begin{array}{l}\text { Healthy } \\
\text { subjects }\end{array}$ & $\begin{array}{l}\text { the SMR group rolled } \\
\text { the surface } \\
\text { of the foot from the } \\
\text { heel to the metatarsal } \\
\text { head using a foam } \\
\text { roller for } 5 \text { minutes. } \\
\text { The sham group } \\
\text { received passive } \\
\text { mobilization } \\
\text { of the ankle joint in the } \\
\text { supine position }\end{array}$ & $\begin{array}{l}2 \text { groups }-S M R \text { and } \\
\text { sham group }\end{array}$ & $\begin{array}{l}\text { Toe Touch test, and } \\
\text { passive straight leg } \\
\text { raise (PSLR) test }\end{array}$ & Yes \\
\hline 20 & 2017 & Wilke et al. & $\begin{array}{l}\text { whether remote } \\
\text { exercise is as } \\
\text { effective as local } \\
\text { stretching }\end{array}$ & $\begin{array}{l}\text { Posterior } \\
\text { chain muscle }\end{array}$ & $\begin{array}{l}\text { Healthy } \\
\text { subjects }\end{array}$ & $\begin{array}{l}\text { Stretching of Lower } \\
\text { limb and cervical spine }\end{array}$ & $\begin{array}{l}3 \text { groups: remote } \\
\text { stretching of the lower } \\
\text { limb (LLS), local } \\
\text { stretching of the } \\
\text { cervical spine (CSS) or } \\
\text { inactive control (CON) }\end{array}$ & maximal cervical ROM & Yes \\
\hline
\end{tabular}




\begin{tabular}{|c|c|c|c|c|c|c|c|c|c|}
\hline SI.No. & Year & Author(s) & Objective & $\begin{array}{l}\text { Myofascial } \\
\text { chain tested / } \\
\text { Identified }\end{array}$ & Population & Intervention & Comparison & $\begin{array}{l}\text { Outcome } \\
\text { measure }\end{array}$ & $\begin{array}{l}\text { Does the result support } \\
\text { existence of Myofascial } \\
\text { connectivity? }\end{array}$ \\
\hline 21 & 2017 & Eid et al. & $\begin{array}{l}\text { study the acute } \\
\text { effects of Ergon }{ }^{\oplus} \\
\text { IASTM Therapy (EIT)3 } \\
\text { application on the } \\
\text { upper part and lower } \\
\text { of the SBL on } \\
\text { hamstrings flexibility. }\end{array}$ & SBL & Healthy subjects & $\begin{array}{l}\text { myofascial EIT } \\
\text { treatment of the } \\
\text { upper part and } \\
\text { lower part of the } \\
\text { SBL }\end{array}$ & $\begin{array}{l}\text { three groups:myofascial } \\
\text { EIT treatment of the } \\
\text { upper part of SBL; } \\
\text { lower part of the SBL; } \\
\text { or served as control } \\
\text { group }\end{array}$ & $\begin{array}{l}\text { a) the Sit and } \\
\text { Reach (SR) test, b) } \\
\text { the passive } \\
\text { straight leg raise } \\
\text { (SLR) test and c) } \\
\text { the Fingertip-to- } \\
\text { Floor (FTF) Test }\end{array}$ & yes \\
\hline 22 & 2016 & Wilke et al. & $\begin{array}{l}\text { potential remote } \\
\text { effects of lower limb } \\
\text { stretching on cervical } \\
\text { range of motion }\end{array}$ & SBL & Healthy subjects & $\begin{array}{l}\text { static stretching for } \\
\text { the gastrocnemius } \\
\text { and the hamstrings }\end{array}$ & $\begin{array}{l}2 \text { groups: Static } \\
\text { stretching versus } \\
\text { inactive controls }\end{array}$ & $\begin{array}{l}\text { maximal cervical } \\
\text { ROM in } \\
\text { flexion/extension }\end{array}$ & Yes \\
\hline 23 & 2016 & Wilke et al. & $\begin{array}{l}\text { the impact of } \\
\text { lower limb exercises } \\
\text { on musculo- } \\
\text { mechanical properties } \\
\text { of } \\
\text { the neighboring } \\
\text { lumbar erector spinae } \\
\text { and hypothesizes } \\
\text { that strain can be } \\
\text { transmitted from the } \\
\text { lower extremity to } \\
\text { the trunk. }\end{array}$ & SBL & Healthy subjects & $\begin{array}{l}\text { (1) stretching of the } \\
\text { gastrocnemius and } \\
\text { the hamstrings, (2) } \\
\text { activation exercises } \\
\text { of the } \\
\text { gastrocnemius and } \\
\text { the hamstrings at } \\
20 \% \text { of the } \\
\text { individual } \\
\text { maximum strength } \\
\text { (3) inactive, seated } \\
\text { control } \\
\text { condition }\end{array}$ & $\begin{array}{l}3 \text { groups: (1) stretching } \\
\text { (2) activation exercises } \\
\text { (3) inactive, seated } \\
\text { control } \\
\text { condition }\end{array}$ & myotonometry & probably \\
\hline 24 & 2016 & Wilke et al. & $\begin{array}{l}\text { To provide evidence } \\
\text { for the existence of } 6 \\
\text { myofascial meridians } \\
\text { proposed by Myers } \\
\text { based on anatomic } \\
\text { dissection studies }\end{array}$ & $\begin{array}{l}\text { the superficial } \\
\text { back line, the } \\
\text { back functional } \\
\text { line, front } \\
\text { functional line, } \\
\text { the spiral line, } \\
\text { the lateral line, } \\
\text { and the } \\
\text { superficial front } \\
\text { line }\end{array}$ & $\begin{array}{l}\text { Systematic review: } \\
\text { Peer-reviewed } \\
\text { human anatomic } \\
\text { dissection studies } \\
\text { reporting } \\
\text { morphologic } \\
\text { continuity between } \\
\text { the muscular } \\
\text { constituents of the } \\
\text { examined meridians }\end{array}$ & systematic review & systematic review & systematic review & Yes; for all except SFL \\
\hline 25 & 2016 & Krause et al. & $\begin{array}{l}\text { to provide a } \\
\text { systematic overview } \\
\text { on tensile } \\
\text { transmission along } \\
\text { myofascial chains }\end{array}$ & $\mathrm{SBL}, \mathrm{BFL}, \mathrm{FFL}$ & $\begin{array}{l}\text { based } \\
\text { on anatomical } \\
\text { dissection studies } \\
\text { and in-vivo } \\
\text { experiments }\end{array}$ & systematic review & systematic review & systematic review & Yes \\
\hline
\end{tabular}




\begin{tabular}{|c|c|c|c|c|c|c|c|c|c|}
\hline SI.No. & Year & Author(s) & Objective & $\begin{array}{l}\text { Myofascial } \\
\text { chain } \\
\text { tested / } \\
\text { Identified }\end{array}$ & Population & Intervention & Comparison & Outcome measure & $\begin{array}{l}\text { Does the result } \\
\text { support existence } \\
\text { of Myofascial } \\
\text { connectivity? }\end{array}$ \\
\hline 26 & 2015 & Grieve, R. & $\begin{array}{l}\text { to investigate the } \\
\text { immediate effect of a } \\
\text { single application } \\
\text { of SMR on the plantar } \\
\text { aspect of the feet, on } \\
\text { hamstring and lumbar } \\
\text { spine flexibility }\end{array}$ & $\begin{array}{l}\text { Posterior } \\
\text { chain } \\
\text { muscle }\end{array}$ & $\begin{array}{l}\text { Healthy } \\
\text { subjects }\end{array}$ & $\begin{array}{l}\text { Self-myofascial } \\
\text { release (SMR) of the } \\
\text { plantar surface of } \\
\text { the foot }\end{array}$ & $\begin{array}{l}2 \text { groups: Self myofascial } \\
\text { release and control }\end{array}$ & sit-and-reach test & Yes \\
\hline 27 & 2014 & $\begin{array}{l}\text { Weisman } \\
\text { et al. }\end{array}$ & $\begin{array}{l}\text { To map the association } \\
\text { of muscle activations } \\
\text { along the superficial } \\
\text { back line (SBL) using } \\
\text { separate conditions of } \\
\text { active range of motion } \\
\text { with and without } \\
\text { resistance and passive } \\
\text { range of motion }\end{array}$ & SBL & $\begin{array}{l}\text { Healthy } \\
\text { subjects }\end{array}$ & $\begin{array}{l}\text { passive movement, } \\
\text { active movement } \\
\text { and active } \\
\text { movement against } \\
\text { maximum isometric } \\
\text { resistance (IR) of the } \\
\text { right gastrocnemius; } \\
\text { and neck extension } \\
\text { without and with } \\
\text { isometric resistance } \\
\text { from prone position. }\end{array}$ & $\begin{array}{l}\text { underwent five test } \\
\text { conditions. Conditions 1-3 } \\
\text { involved passive movement, } \\
\text { active movement and active } \\
\text { movement against maximum } \\
\text { isometric resistance (IR) of } \\
\text { the right gastrocnemius and } \\
\text { conditions } 4 \text { and } 5 \text { involved } \\
\text { neck extension without and } \\
\text { with isometric resistance } \\
\text { from prone position. }\end{array}$ & surface electromyography & Yes \\
\hline 28 & 2013 & $\begin{array}{l}\text { Hyong et } \\
\text { al. }\end{array}$ & $\begin{array}{l}\text { to examine the } \\
\text { immediate effects of } \\
\text { passive hamstring } \\
\text { stretching exercises on } \\
\text { cervical spine range of } \\
\text { motion and balance }\end{array}$ & $\begin{array}{l}\text { Posterior } \\
\text { chain } \\
\text { muscle }\end{array}$ & $\begin{array}{l}\text { Healthy } \\
\text { subjects }\end{array}$ & $\begin{array}{l}\text { The experimental } \\
\text { group were } \\
\text { administered } \\
\text { hamstring stretching } \\
\text { with ankle } \\
\text { dorsiflexion for } 30 \\
\text { seconds three times, } \\
\text { whereas the control } \\
\text { group received the } \\
\text { same treatment } \\
\text { without ankle } \\
\text { dorsiflexion }\end{array}$ & $\begin{array}{l}2 \text { groups: experimental and } \\
\text { control }\end{array}$ & $\begin{array}{l}\text { cervical range of motion } \\
\text { goniometer, and balance using } \\
\text { TETRAX Portable Multiple } \\
\text { System }\end{array}$ & Yes \\
\hline 29 & 2013 & $\begin{array}{l}\text { Bolívar et } \\
\text { al. }\end{array}$ & $\begin{array}{l}\text { to determine whether } \\
\text { tightness of the } \\
\text { posterior muscles of } \\
\text { the lower extremity } \\
\text { was associated with } \\
\text { plantar fasciitis. }\end{array}$ & $\begin{array}{l}\text { Posterior } \\
\text { chain } \\
\text { muscle }\end{array}$ & $\begin{array}{l}\text { Subjects } \\
\text { with } \\
\text { plantar } \\
\text { fascitis }\end{array}$ & Observational study & $\begin{array}{l}2 \text { groups: experimental and } \\
\text { control }\end{array}$ & $\begin{array}{l}\text { Tightness of Hamstring and calf } \\
\text { muscles were evaluated } \\
\text { through the straight leg } \\
\text { elevation test, popliteal angle } \\
\text { test, and ankle dorsiflexion }\end{array}$ & Yes \\
\hline 30 & 2011 & $\begin{array}{l}\text { Labovitz } \\
\text { et al. }\end{array}$ & $\begin{array}{l}\text { to determine if } \\
\text { hamstring tightness } \\
\text { was an increased risk } \\
\text { in plantar fasciitis }\end{array}$ & $\begin{array}{l}\text { Posterior } \\
\text { chain } \\
\text { muscle }\end{array}$ & $\begin{array}{l}\text { Subjects } \\
\text { with } \\
\text { plantar } \\
\text { fascitis }\end{array}$ & Observational study & $\begin{array}{l}2 \text { groups: experimental and } \\
\text { control }\end{array}$ & $\begin{array}{l}\text { Body mass index (BMI), the } \\
\text { presence of plantar fasciitis, } \\
\text { equinus, and calcaneal spurs } \\
\text { were assessed. The popliteal } \\
\text { angle was measured. }\end{array}$ & Yes \\
\hline
\end{tabular}




\begin{tabular}{|c|c|c|c|c|c|c|c|c|c|}
\hline SI.No. & Year & Author(s) & Objective & $\begin{array}{l}\text { Myofascial } \\
\text { chain } \\
\text { tested / } \\
\text { Identified }\end{array}$ & Population & Intervention & Comparison & Outcome measure & $\begin{array}{l}\text { Does the result } \\
\text { support existence of } \\
\text { Myofascial } \\
\text { connectivity? }\end{array}$ \\
\hline 31 & 2010 & $\begin{array}{l}\text { Bezuidenhout, } \\
\text { J. }\end{array}$ & $\begin{array}{l}\text { to determine the effect } \\
\text { of chiropractic spinal } \\
\text { manipulative therapy } \\
\text { compared to that of } \\
\text { fascial treatment on } \\
\text { SBL fascial line } \\
\text { restrictions }\end{array}$ & SBL & $\begin{array}{l}\text { asymptomatic } \\
\text { subjects }\end{array}$ & $\begin{array}{l}\text { Chiropractic } \\
\text { SMT and Direct } \\
\text { MFR technique }\end{array}$ & $\begin{array}{l}2 \text { groups: } \\
\text { Chiropractic SMT } \\
\text { and Direct MFR } \\
\text { technique to the } \\
\text { restricted SBL }\end{array}$ & $\begin{array}{l}\text { Bunkie test and ROM test to } \\
\text { determine level of endurance } \\
\text { and fascial line restrictions } \\
\text { respectively }\end{array}$ & Yes \\
\hline 32 & 2001 & $\begin{array}{l}\text { Halbertsma et } \\
\text { al. }\end{array}$ & $\begin{array}{l}\text { To investigate the } \\
\text { extensibility and } \\
\text { stiffness of the } \\
\text { hamstrings in patients } \\
\text { with nonspecific low } \\
\text { back pain (LBP) }\end{array}$ & $\begin{array}{l}\text { Posterior } \\
\text { chain } \\
\text { muscle }\end{array}$ & LBP subjects & $\begin{array}{l}\text { Straight leg } \\
\text { raising, pulling } \\
\text { force, and } \\
\text { activity of } \\
\text { hamstring and } \\
\text { back muscles } \\
\text { were recorded }\end{array}$ & $\begin{array}{l}3 \text { groups: LBP } \\
\text { subjects, and } \\
\text { healthy controls - } \\
\text { flexible and stiff } \\
\text { group. }\end{array}$ & $\begin{array}{l}\text { The lift force, leg excursion, } \\
\text { pelvic-femoral angle, first } \\
\text { sensation of pain, and the } \\
\text { electromyogram of the } \\
\text { hamstrings and back muscles } \\
\text { measured in an experimental } \\
\text { straight-leg raising set-up }\end{array}$ & probably \\
\hline 33 & 2001 & Feldman et al. & $\begin{array}{l}\text { to } \\
\text { determine the } \\
\text { incidence of low back } \\
\text { pain in a cohort of } \\
\text { adolescents and to } \\
\text { ascertain risk factors }\end{array}$ & unclear & adolescents & $\begin{array}{l}\text { evaluated } \\
\text { during } 1995- \\
1996 \text { at three } \\
\text { separate times, } \\
6 \\
\text { months apart }\end{array}$ & - & low back pain occurrence & May be \\
\hline 34 & 1996 & $\begin{array}{l}\text { Tafazzoli, F. } \\
\text { and } \\
\text { Lamontagne, } \\
\text { M }\end{array}$ & $\begin{array}{l}\text { to measure and } \\
\text { compare the passive } \\
\text { elastic moment, the } \\
\text { stiffness and the } \\
\text { damping coefficient of } \\
\text { the hip joint, as } \\
\text { functions of the hip and } \\
\text { knee joint angles in } \\
\text { men with and without } \\
\text { low-back pain }\end{array}$ & unclear & LBP subjects & $\begin{array}{l}\text { The passive } \\
\text { elastic moment } \\
\text { was measured } \\
\text { using an } \\
\text { isokinetic device } \\
\text { in the passive } \\
\text { mode }\end{array}$ & $\begin{array}{l}2 \text { groups: LBP and } \\
\text { healthy controls }\end{array}$ & Isokinetic device & May be \\
\hline
\end{tabular}




\section{Discussion}

Fascial connectivity and musculoskeletal dysfunctions

Direct morphologic coherence between neighboring muscles provides a factual basis to broaden the diagnostic and therapeutic focus beyond a single anatomic structure (Leonard, 2013). For instance, in patients with low back pain, treatment directed towards neighboring or remote myofascial structures via specific fascial connectivity could prove to be effective in reducing pain (Grieve et al., 2015). Several studies support the observation that patients with low back pain most often present with reduced hamstring flexibility (Tafazzoli, \& Lamontagne., 1996; Halbertsma et al., 2001). It has been shown that relieving the tension of the posterior thigh muscles could be a conceivable approach to alleviate low back pain (Feldman et al., 2001; Hultman et al., 1992). As per the myofascial meridian concept, both these regions form a part of the SBL (Superficial back line), a fascial connectivity that extends from head to toe through the posterior aspect of the body. Overload disorders in contact sports are another pathological entity that can occur due to the existence of myofascial meridians (Myers 2014; Wilke et al., 2016a).

Similar to previously mentioned research exploring direct morphologic coherence, Labovitz et al. (2011) and Bolivar et al. (2013) studied the indirect link between remote myofascial structures. They pointed out that poor extensibility of gastrocnemius and hamstrings muscles may be associated with plantar fasciitis (PF). Since gastrocnemius, hamstring and plantar aponeurosis belong to the SBL, they might represent a focus for therapy when one or the other structure is affected by trauma or overuse. This aspect was studied by Labovitz et al., (2011) in a prospective cohort study (CEBM grade $2 \mathrm{~b}$ ) with an aim to find out if hamstring tightness was an increased risk in PF. They found out that patients with hamstring tightness were about 8.7 times more likely to experience PF in the corresponding foot compared with patients without hamstring tightness. In a case-control analysis (CEBM grade $3 \mathrm{~b}$ ), Bolivar et al. had tested essentially the same hypothesis with 100 participants in 2013, and concluded that the tightness of the posterior muscles of the lower limb was significantly correlating with the incidence of PF. Both these studies suggest that assessment of PF should include evaluation of hamstring tightness and triceps surae muscles and incorporate a stretching protocol for the same as one of the treatments. Since both studies were in a non-randomized format, caution is needed in interpreting their findings and their generalizability. It also necessitates high-quality confirmation studies to establish these findings.

In 2015, Grieve et al., investigated the immediate effect of a single application of Self Myofascial Release (SMR) on the plantar aspect of the foot on hamstring and lumbar spine flexibility. A pilot single-blind RCT was conducted (CEBM 2b; PEDro 4/10) with 24 healthy volunteers. They noted a significant increase in the hamstring and lumbar spine flexibility when compared to the control group, with a large effect size. He suggested that flexibility interventions based on myofascial chains, especially the SBL, cause force transmission to occur along the myofascial chain resulting in non-local effects. A result from an in vivo study by Tijs et al (2018) is worth mentioning here as this study specifically tested myofascial force transmission and fascicle length change during myofascial loading by studying the mechanical interaction properties between Soleus and its synergists. This animal study assessed whether myofascial loads exerted by the neighboring muscles result in length changes of Soleus fascicles and found that myofascial force transmission can occur between a prime mover (soleus) and synergistic muscles via connective tissue networks without substantial length changes of the fascicles.

In 2016, Krause et al., conducted a systematic review on intermuscular force transmission along the myofascial chains based on cadaveric studies and in-vivo experiments. This systematic analysis concluded that the tension / force between at least some of the neighboring myofascial structures under investigation can be transferred. Even though the study is concluding positively, the authors quoted that the current results' implication to in-vivo conditions could be limited and suggested that such experiments be done on fresh cadavers, as fixation, as well as freezing and thawing, could alter its biomechanical properties. Furthermore, future research on the in-vivo nature of adjacent structures will explore further the practical significance of the suggested intermuscular myofascial associations for prescription exercise, injury prevention and rehabilitation.

In the same year, Wilke et al., (2016b) evaluated the remote effects of lower limb stretching on cervical range of motion (ROM) based on the myofascial meridians and found that lower extremity stretching induced improvements of cervical range of motion and indicated the existence of strain transfer along the course of myofascial meridians. This was a pilot study with a matched-pair comparison (CEBM scale: $3 b$ ). These findings need to be verified by randomised, controlled trials with adequate sample size. The authors also pointed towards the limitations of the outcome measure used as it could not identify whether an increase in flexibility was attained in flexion, pointing towards a measurement bias. Wilke et al, has another conference abstract in 2016c, a randomized, cross-over trial with 13 asymptomatic subjects (PEDro=Unknown (abstract); CEBM scale:2b) The aim was to find out the impact of lower limb exercises on the lumbar erector spinae properties. They found a slight impact of stretching on the elasticity of the lumbar erector spinae. Again, this finding needs to be tested with high-quality trials to have more conclusive evidence in order to prove the myofascial continuity. A recently published single blinded RCT (Joshi et al., 2018) (PEDro: 7/10; CEBM 2b) conducted a study on 58 asymptomatic participants with tight hamstrings and reported that remote myofascial release (MFR) either in the sub occipital region or the plantar fascia has an effect on hamstring flexibility equivalent to the static stretching of hamstring, supporting their hypothesis of myofascial tensegrity. The study has major methodological imperfections influencing its reliability, yet it is recommendable as initial supportive literature for myofascial connectivity.

Wilke et al., (2017a) conducted a medium quality (PEDro : $6 / 10$, CEBM: 2 b) randomized controlled study on sixty-three healthy participants to compare the effectiveness of remote stretching based on myofascial chains with local exercise on cervical range of motion (ROM). The participants were assigned randomly to one of the three groups: remote lower limb stretching (LLS), local cervical spine stretching (CSS), or inactive control (CON). Pre (M1), immediate post (M2), and average cervical ROM five minutes after intervention (M3) were measured. Both LLS and CSS increased cervical ROM in all movement planes and at all measurements $(P<$ .05) compared with the control group. No statistical differences were noticed between LLS and CSS ( $P>$.05). The study concluded that lower limb stretching based on myofascial chains causes 
comparable acute changes to local exercise in cervical ROMs. Methodological flaws and inadequate power hinders the study's generalizability. The authors have given a caution in the interpretation section as "attained effects do not seem to be direction-specific, further research is warranted in order to provide evidence-based recommendations".

Wilke et al., (2019a) conducted a regression experimental study (CEBM $=3)$, which examined the age-dependency of the remote exercises on myofascial force transmission. The authors examined the result of age on these myofascial force transmissions in 168 healthy individuals between 13 and 87 years by using a prepost regression analysis process. The results suggested that age and baseline flexibility predicted changes in hamstring extensibility and recommended further high quality trials.

Recent research by Song et al., (2019) studied the effects of myofascial meridians release technique using either the Grastone massage or the Rolfing massage techniques for improving pain and postural control of those with forward head posture ( $P$ EDro $=4 / 10$; $\mathrm{CEBM}=2 \mathrm{~b}$;). The study was conducted among 30 college students randomly allocated to either of the two groups and intervention was provided for six weeks. SBL was chosen as the meridian for the application of the above techniques. All measured outcomes of numeric pain rating, neck disability index and forward head posture improved in both groups with the group receiving Grastone massage based myofascial meridians release showing superior results. However, factors that may have affected the outcomes of the study include the subjects also receiving physiotherapy in the form of pain relieving electrotherapeutic and mechanical modalities, and studying subjects who could conduct their daily living activities without any difficulty. Hence the confidence with which the results can be relied upon or generalized is fairly limited. Another researcher, Sulowska et al., in this same year studied the influence of short plantar foot muscle exercises on lower extremity muscle strength and power among 47 long distance runners (PEDro= 5/10; CEBM= 2b). Participants were grouped based on the foot posture index and trained for 6 weeks with specific intrinsic foot muscle exercises besides their regular running training. The outcome measures they used were highly objective, which included torque, work and strength of knee flexors and extensors on the Isokinetic Dynamometer and Running-Based Anaerobic Sprint Test (RAST). This research did not have any major limitations besides the heterogeneity of subjects due to variation in their running distance. The results reported were very interesting, whereby, both strength and power of proximal segments of the kinetic chain increased after the exercises for plantar short foot muscles, which are part of the SBL as per the anatomy trains concept. These findings are again indicative of the fact that myofascial continuity and its role in energy transfer is a reality, and that this energy transfer takes place along specific lines that may be likened to myofascial meridians.

Fousekis et al., (2019) in a randomized controlled trial (PEDro $=7 / 10 ; C E B M=2 b$ ) studied the effects of local vs. remote application of the 'instrumental assisted soft tissue mobilization (IASTM)' treatment on the superficial back line by evaluating the hamstring flexibility. Sixty university students were randomly divided into three sub-groups and received a single 15-minute treatment with IATSM Technique in a) the upper and b) the lower part of SBL or c) served as control. The participants received one session per week for four weeks with a simultaneous pre-and post-therapy assessment. The authors found that hamstring flexibility, as measured by the passive SLR test, improved significantly in both the treatment groups when compared to the control group. There was no significant difference between local or remote application of IATSM treatment. IASTM treatment of either the upper or lower part of the superficial back line may lead to a significant increase in hamstrings flexibility and the authors are attributing this to the myofascial continuity. In a similar medium quality (CEBM $2 \mathrm{~b}$; Pedro 5/10) study, Fousekis et al., (2019) found that application of IATSM technique of either the upper or lower part of the SBL will lead to a substantial increase in flexibility in the hamstring regardless of the site of application. An abstract of RCT published by Eid et al., (2017) also describes that IASTM of the trunk and lower extremities improved the hamstring flexibility. As mentioned earlier, a majority of these results need to be interpreted with utmost care because of the methodological imperfections and reliability issues.

A high quality RCT (PEDro=8/10; CEBM $=2$ b) by Marizeiro et al., (2018) found that application of Myofascial release in the diaphragmatic region in sedentary women improved not only the chest wall mobility but superficial back line muscle and lumbar spine flexibility also. It is appraisable that more and more studies are adding to the literature of myofascial connectivity even though only very few are connecting this to the myofascial meridians as defined here. A re-search on December 2019 identified six more articles reporting interventions related to Superficial back line (Do et al., 2018; Williams and Selkow., 2019; Wang., 2019; Paloncy et al., 2019; Chakhuttray et al., 2019; Bezuidenhout., 2010) and few more studies mentioning the myofascial connectivity (Devereux et al., 2019; Danyschuk., 2019; Borg et al., 2019; Zhang., 2019). The myofascial connectivity is often a secondary finding in many studies and the introduction of all these findings is beyond the scope of this narrative review.

A recent meta-analysis by Burk et al (2019) $(C E B M=2 a)$ analyzed the remote effect of myofascial interventions with range of motion as the dependent variable. They found eight randomized controlled trials of lower methodological quality (PEDro score 2-7), comprising 354 participants focusing on SBL. Pooled results for ROM showed trends in favor of remote interventions at immediate followups, but with small effect size. The study concluded that remote exercise may increase ROM at distant body segments, but cautioned on result generalizability due to the methodological concerns.

\section{Electromyography and myofascial meridians}

Weisman and colleagues (2014) attempted to map the association of muscle activation along the SBL using separate conditions of active ROM with and without resistance, and passive ROM (CEBM 3b). They studied 20 healthy adult males undergoing five test conditions, with surface EMG electrodes placed along the specific points of the SBL. The findings revealed a strong correlation between muscle activations in the test condition and muscle activations along the adjacent SBL. The study indicated a need for a complete evaluation of the SBL in patients suffering from myofascial pain anywhere along it.

Recently, another researcher, Vulfsons et al., (2018) analyzed the surface electromyographic changes along the 'superficial backline' of chronic nonspecific low back pain patients in a case control study (CEBM 3b) with 20 low back pain patients and 17 age matched controls. The study found a significant difference in activation of the muscles belonging to the superficial back line between the groups. The results of both the studies should be interpreted with caution due to the study design used and the bias it can generate. Moreover, surface EMG has inherent limitations as 
opposed to intra-muscular EMG recording, which can be an important factor that may have influenced their findings.

Raţă et al in 2018 published a case study on morpho-functional implications of myofascial stretching applied to muscle chains. The authors investigated the influence of static stretching at a 24-yearold athlete with Haglund's disease on the electromyographic function of muscle chains. They found that a two month stretching program of 60 minutes, two sessions per week resulted in a rebalancing of the maximum volumetric isometric contraction across various myofascial connections and recommended the static stretching as an effective treatment method for shortened muscle chains. A single case study with surface EMG findings is not a definitive answer but opens a window for further research along these lines

\section{Do Myofascial Meridians really exist?}

The concept of myofascial meridians or myofascial chains has been explored in numerous studies (Hyong \& Kang 2013; Weisman et al., 2014; Grieve 2015). Wilke et al. (2016a) were the first to conduct a methodologically high quality systematic review of anatomy dissection studies adhering to PRISMA guidelines, exploring the existence of meridians. Their search for published literature spanned more than a century, from 1900to 2014. The methodological quality of the included studies was evaluated by using QUACS scale (Quality Appraisal for Cadaveric Studies) by two independent evaluators. Proof of each meridian and its transitions has been graded as solid, moderate, minimal, conflicting or nonexistent (Wilke et al., 2016a). A change was deemed a myofascial link between two muscles. For example, the gastrocnemius and hamstring muscles are regarded as a transition of the SBL. They discovered evidence for the existence of three myofascial chains proposed by Myers (Myers 2009 \& 2014). The results provided strong evidence for myofascial transitions in three of the six examined myofascial meridians: SBL, BFL and FFL. In the SBL, 3 myofascial transitions (plantar fascia-gastrocnemius, gastrocnemiushamstrings, and hamstrings-lumbar fascia/erector spine) were verified in fifteen studies. In the BFL, three myofascial transitions were verified in 8 studies (latissimus-lumbar fascia, lumbar fasciagluteus maximus, and gluteus maximus-vastus lateralis). Six studies supported two myofascial transitions (pectoralis major-rectus abdominis and rectus abdominis-adductor longus) for the FFL with a 'strong evidence' grade. There was only moderate evidence supporting the meridians and transitions of the spiral line and the lateral line. There was no evidence for the meridians and transitions of the SFL, which was based on seven studies (Wilke et al., 2016a). The practical pertinence of the findings of this systematic review reconnects us to the existence of myofascial meridians as suggested by Myers (2014) or as believed by the manual therapists. This will facilitate and justify the idea of how lines of pull and compensations in one structure or part of the body impact other distant/remote structures or parts. These findings may lead to the development of more suitable intervention strategies by manual and movement therapists for their patients.

Wilke and Krause have done another systematic review with peer-reviewed anatomical dissection studies in 2019(b) in order to find evidence of structural continuity between the trunk and upper extremity skeletal muscles. Thirteen studies, which were evaluated with QUACS scale for the methodological quality, were included in this review. The analysis revealed the presence of three myofascial connectivity between the trunk and the upper extremity: the ventral arm chain, the lateral arm chain, and the dorsal arm chain with clear proof of direct serial tissue connectivity from neck and shoulder area to forearm. The study concluded with the recommendation for further research to establish the mechanical relevance of the identified myofascial chains before any definitive conclusion.

The majority of the reviewed studies did not explicitly look for the finding of fascial connectivity but mentioned them as a subordinate finding. The systematic reviews by Wilke et al, Krause et al and Burk et al succeeded in tracing the presence of myofascial continuity with a higher level of evidence, but with methodological issues that need to be mentioned. Future research will resolve those limitations and rectify them. Overall, the findings from these systematic reviews can be considered as a starting point for further high-quality studies in the search for the existence of strain transmissions across tissues connected by myofascial meridians.

\section{Pitfalls in myofascial meridian research}

As pointed out by Krause et al., (2016), factors that are having an effect on the applicability of these findings should be mentioned and if possible managed in the upcoming studies. Factors like (i) heterogeneity in methods of force application, (ii) variation in the measured outcomes and methods between studies and examined body regions and (iii) factors related to the use of cadaver specimen for biomechanical testing (Krause et al., 2016) should be managed in future studies. These limitations are also applicable to research findings presented by other authors and need critical review for meaningful interpretation of the study results. Consideration of anatomical differences in continuity, as well as histological variations in the connecting structures is also important when interpreting performance. This is an issue that several researchers have failed to address. While considering the experimental studies, to have high quality evidence, appraise and organise the studies with good quality designs, randomization and double-blinding first (Ajimsha \& Shenoy 2019). One should understand that a systematic review is not necessarily superior to a well-conducted RCT, and not all RCTs are necessarily superior to observational studies of good methodological quality (Ajimsha \& Shenoy 2019). Authors should use their critical appraisal skills to interpret any research evidence before applying them to clinical practice.

\section{Directions for future research}

Future studies should include RCTs of in-vitro studies as most of the current experimental research was done using cadavers (Nortonold., et al 2013; Barker et al., 2004). It will be valuable to direct additional research on the other proposed myofascial meridians. This will help to substantiate their existence with sufficient evidence and begin to explore the existence of other lines. A clinician may use the myofascial meridians as a conclusive orientation, but they should be aware that the functional implications are yet to be studied (Wilke et al., 2016a). Currently, an increasing number of clinicians and anatomists show continued interest and enthusiasm on the subject of myofascia, hence the possibility of further research focused on the existence of myofascial links remains very high (van der Wal 2009). The objective reality of myofascial meridians might serve as a breakthrough in explaining several phenomena that lack a clear understanding of their etiology 
or pathophysiology even today. One such example is referred pain, which frequently occurs in nonspecific disorders and is almost often difficult to explain. Another example is that of myofascial trigger points of the calf that provokes radiating pain to the sole of the foot and the dorsal thigh (Travell \& Simons 1992).

\section{Limitations}

In spite of our best efforts to perform this review, it has several limitations that are inherent to any narrative review. Although every effort was made to minimize selection and evaluation bias, we accept the fact that this study lacks a reproducible search strategy and the methodological rigor of a systematic review.

\section{Conclusion}

Albeit these reviews and trials yield positive evidence for the existence of fascial connectivity and continuity, several aspects need further clarification and in-depth analysis. We need high quality randomized controlled in-vivo trials and biomechanical studies to ascertain the above findings as most of the current studies are either in non-randomized format or with inadequate methodological quality that prevents the generalizability of the results. Future research should focus on determining the presence of the meridians and force transmissions in a more objective and reliable way which could not be evidenced entirely in the work cited in this review. Definitely, it is of utmost significance to explain the functional importance of the myofascial chains as the ability for strain transition represents the decisive criterion to legitimize the treatment of meridians. Another issue is related to the function of regional specializations or myofascial expansions which so far stay indistinct. Manual and physical therapists may utilize the concept of fascial connectivity/meridians as a convincing justification but should be vigilant that functional implications remain to be investigated.

\section{Disclosure statement}

The authors report no declarations of interest.

\section{Acknowledgments}

We wish to express our profound gratitude to Mr. Vasileios Karpouzis for his assistance with manuscript language.

\section{References}

1) Ajimsha MS. (2018). Myofascial release as a treatment choice for neuromuscular conditions: three randomized controlled trials and a systemic literature review (Doctoral dissertation, University of Bolton in association with New York College Athens).

2) Ajimsha, MS. and Shenoy, P.D. (2019). Improving the quality of myofascial release research-A critical appraisal of systematic reviews. Journal of Bodywork and Movement Therapies.

3) Arnsdorf, E.J., Tummala, P., Castillo, A.B., Zhang, F. and Jacobs, C.R. (2010). The epigenetic mechanism of mechanically induced osteogenic differentiation. Journal of biomechanics, 43(15), pp.2881-2886

4) Barker, P.J., Briggs, C.A. and Bogeski, G. (2004). Tensile transmission across the lumbar fasciae in unembalmed cadavers: effects of tension to various muscular attachments. Spine, 29(2), pp.129-138

5) Bezuidenhout, J. (2010). A comparison between manipulative therapy and fascial treatment in treating fascial line dysfunction of the superficial back line (Doctoral dissertation, University of Johannesburg).

6) Bolívar, Y.A., Munuera, P.V. and Padillo, J.P. (2013). Relationship between tightness of the posterior muscles of the lower limb and plantar fasciitis. Foot \& Ankle International, 34(1), pp.42-48

7) Borg, H., Bohlin, H. and Ranje-Nordin, C., 2019. Can Myofascial Treatment with Pulsating Vibrations Improve Mobility for Patients with Frozen Shoulder. A Case Study. J Case Rep Stud, 7(5), p.504.

8) Bordoni, B. and Simonelli, M. (2018). The awareness of the fascial system. Cureus, 10(10).

9) Burk, C., Perry, J., Lis, S., Dischiavi, S. and Bleakley, C. (2019). Can Myofascial Interventions Have a Remote Effect on ROM? A Systematic Review and Meta-Analysis. Journal of Sport Rehabilitation, 1(aop), pp.1-23.

10) Chaitow, L. (2016). New evidence of a dynamic fascial maintenance and self-repair process. Journal of bodywork and movement therapies, 20(4), pp.701-703

11) Chakhuttray, C., Siritaratiwat, W., Mator, L. and Boonprakob, Y. (2019). Immediate effect of the rubber hammer on flexibility of superficial back line. Journal of Medical Technology and Physical Therapy, 31(1), pp.63-73

12) Chen, Y.H., Chai, H.M., Shau, Y.W., Wang, C.L. and Wang, S.F. (2016). Increased sliding of transverse abdominis during contraction after myofascial release in patients with chronic low back pain. Manual therapy, 23, pp.69-75

13) Danyschuk, A. (2019). Influence of lower leg myofascial kinematic chains on flat feet development of children 7-14 years old. Health, sport, rehabilitation, 5(2), pp.28-35.

14) Devereux, F., O'Rourke, B., Byrne, P.J., Byrne, D. and Kinsella, S., 2019. Effects of Myofascial Trigger Point Release on Power and Force Production in the Lower Limb Kinetic Chain. The Journal of Strength \& Conditioning Research, 33(9), pp.2453-2463.

15) Dischiavi, S.L., Wright, A.A., Hegedus, E.J. and Bleakley, C.M. (2018). Biotensegrity and myofascial chains: A global approach to an integrated kinetic chain. Medical hypotheses, 110, pp.90-96.

16) Do, K., Kim, J. and Yim, J. (2018). Acute effect of selfmyofascial release using a foam roller on the plantar fascia on hamstring and lumbar spine superficial back line flexibility. Physical Therapy Rehabilitation Science, 7(1), pp.35-40.

17) Dodd, J.G., Good, M.M., Nguyen, T.L., Grigg, A.I., Batia, L.M. and Standley, P.R. (2006). In vitro biophysical strain model for understanding mechanisms of osteopathic manipulative treatment. Journal of the American Osteopathic Association, 106(3), p.157

18) Eid, K., Tafas, E., Mylonas, K., Angelopoulos, P., Tsepis, E. \& Fousekis, K. (2017). Treatment of the trunk and lower extremities with Ergon $^{\circledR}$ IASTM technique can increase hamstrings flexibility in amateur athletes: A randomized control study. Physical Therapy in Sport, 28, e12.

19) Ercole, B., Antonio, S., Ann, D.J. and Stecco, C. (2010). How much time is required to modify a fascial fibrosis?.Journal of bodywork and movement therapies, 14(4), pp.318-325

20) Feldman, D.E., Shrier, I., Rossignol, M. and Abenhaim, L. (2001). Risk factors for the development of low back pain in adolescence. American Journal of Epidemiology, 154(1), pp.30-36

21) Findley, T. and Shalwala, M. (2013). Fascia research congress evidence from the 100 year perspective of 
Andrew Taylor Still. Journal of Bodywork and Movement Therapies, 17(3), pp.356-364

22) Fousekis, K., Eid, K., Tafa, E., Gkrilias, P., Mylonas, K., Angelopoulos, P., Koumoundourou, D., Billis, V. and Tsepis, E. (2019). Can the application of the Ergon ${ }^{\circledR}$ IASTM treatment on remote parts of the superficial back myofascial line be equally effective with the local application for the improvement of the hamstrings' flexibility? A randomized control study. Journal of physical therapy science, 31(7), pp.508-511.

23) Grieve, R. (2015). The immediate effect of bilateral self myofascial release on the plantar surface of the feet on hamstring and lumbar spine flexibility: A pilot randomised controlled trial. Journal of bodywork and movement therapies, 19(3), pp.544-552

24) Halbertsma, J.P., Göeken, L.N., Hof, A.L., Groothoff, J.W. and Eisma, W.H. (2001). Extensibility and stiffness of the hamstrings in patients with nonspecific low back pain. Archives of physical medicine and rehabilitation, 82(2), pp.232-238.

25) Hultman, G., Saraste, H. and Ohlsen, H. (1992). Anthropometry, spinal canal width, and flexibility of the spine and hamstring muscles in 45-55-year-old men with and without low back pain. Clinical Spine Surgery, 5(3), pp.245-253

26) Hyong, I.H. and Kang, J.H. (2013). The immediate effects of passive hamstring stretching exercises on the cervical spine range of motion and balance. Journal of Physical Therapy Science, 25(1), pp.113-116

27) Joshi, D.G., Balthillaya, G. and Prabhu, A. (2018). Effect of remote myofascial release on hamstring flexibility in asymptomatic individuals-A randomized clinical trial. Journal of bodywork and movement therapies, 22(3), pp.832-837.

28) Krause, F., Wilke, J., Vogt, L. and Banzer, W. (2016). Intermuscular force transmission along myofascial chains: a systematic review. Journal of anatomy, 228(6), pp.910918.

29) Kumka, M. and Bonar, J. (2012). Fascia: a morphological description and classification system based on a literature review. The Journal of the Canadian Chiropractic Association, 56(3), p.179.

30) Kwong, E.H. and Findley, T.W.(2014). Fascia-Current knowledge and future directions in physiatry: Narrative review. Journal of Rehabilitation Research \& Development, 51(6)

31) Labovitz, J.M., Yu, J. and Kim, C. (2011). The role of hamstring tightness in plantar fasciitis. Foot \& ankle specialist, 4(3), pp.141-144

32) Langevin, H.M., Fox, J.R., Koptiuch, C., Badger, G.J., Greenan-Naumann, A.C., Bouffard, N.A., Konoifagou, E.E., Lee, W.N., Triano, J.J. and Henry, S.M. (2011). Reduced thoracolumbar fascia shear strain in human chronic low back pain. musculoskeletal disorders, 12(1), pp.203

33) Leonard, J. (2013). Importance of considering myofascial force transmission in musculoskeletal surgeries. J Surg Acad 3(2), pp.1-3.

34) Liptan, G.L. (2010). Fascia: A missing link in our understanding of the pathology of fibromyalgia. Journal of Bodywork and Movement Therapies, 14(1), pp.3-12

35) Liu, W. F. (2018). Control by cell size. Nature materials, 17(12), pp.1055
36) Luomala, T. and Pihlman, M. A Practical Guide to Fascial Manipulation: An Evidence-and Clinical-Based Approach (1 $1^{\text {st }}$ ed). 2016 Elsevier Health Sciences

37) Maas, H. (2019). Significance of epimuscular myofascial force transmission under passive muscle conditions. Journal of Applied Physiology, 126(5), pp.14651473.

38) Maas, H. and Sandercock, T.G. (2010). Force transmission between synergistic skeletal muscles through connective tissue linkages. BioMedResearch International,

39) Maher, C.G., Sherrington, C., Herbert, R.D., Moseley, A.M. and Elkins, M. (2003). Reliability of the PEDro scale for rating quality of randomized controlled trials. Physical therapy, 83(8), pp.713-721

40) McKenney, K., Elder, A.S., Elder, C. and Hutchins, A. (2013). Myofascial release as a treatment for orthopaedic conditions: a systematic review. Journal of athletic training, 48(4), pp.522-527

41) McKeon, P.O., Medina, J.M. and Hertel, J. (2006). Hierarchy of evidence-based clinical research in sports medicine. Athletic Ther Today, 11, pp.42-45

42) Medina, J.M., McKeon, P.O. and Hertel, J. (2006). Rating the levels of evidence in sports-medicine research. Athletic Therapy Today, 11(5), pp.38-41

43) Meltzer, K.R., Cao, T.V., Schad, J.F., King, H., Stoll, S.T. and Standley, P.R. (2010). In vitro modeling of repetitive motion injury and myofascial release. Journal of bodywork and movement therapies, 14(2), pp.162-171

44) Marizeiro, D.F., Florêncio, A.C.L., Nunes, A.C.L., Campos, N.G. and de Paula Lima, P.O. (2018). Immediate effects of diaphragmatic myofascial release on the physical and functional outcomes in sedentary women: A randomized placebo-controlled trial. Journal of bodywork and movement therapies, 22(4), pp.924-929.

45) Myers T.W. (2009). Anatomy trains: myofascial meridians for manual and movement therapists. 2nd ed. Edinburgh: Churchill Livingstone;

46) Myers T.W. (2014). Anatomy Trains: Myofascial Meridians for Manual and Movement Therapists. London: 3rd ed; Churchill Livingstone;

47) Norton-Old, K.J., Schache, A.G., Barker, P.J., Clark, R.A., Harrison, S.M. and Briggs, C.A. (2013). Anatomical and mechanical relationship between the proximal attachment of adductor longus and the distal rectus sheath. Clinical Anatomy, 26(4), pp.522-530

48) Paloncy, K.A., Wilhite, C., Daniel, T. and Rakowoski, K. (2019). Clinician Versus Self-Administered Suboccipital Release on Superficial Backline Function. Clinical Practice in Athletic Training, 2(2), pp.12-19.

49) Phillips, B., Ball, C., Sackett, D., Badenoch, D., Straus, S., Haynes, B. and Daves, M. (2009). Oxford Centre for Evidence-based Medicine Levels of Evidence. Available from URL: http://www.cebm.net/?oZ1025 (accessed March January 11, 2012).

50) Raţă, B.C., Raţă, M. and Antohe, B. (2018). Morphofunctional implications of myofascial stretching applied to muscle chains: A case study. Journal of back and musculoskeletal rehabilitation, 31(4), pp.749-758.

51) Schilder, A., Magerl, W., Klein, T. and Treede, R.D. (2018). Assessment of pain quality reveals distinct differences between nociceptive innervation of low back fascia and muscle in humans. Pain reports, 3(3). 
52) Schleip, R., Chaitow, L., Findley, T.W., and Huijing, P. (2012). Fascia -The Tensional Network of the Human Body. The Science and Clinical Applications in Manual and Movement Therapy. Edinburgh: Elsevier

53) Schleip, R. and Müller, D.G. (2013). Training principles for fascial connective tissues: scientific foundation and suggested practical applications. Journal of bodywork and movement therapies, 17(1), pp.103-115

54) Snow, S.W., Bohne, W.H., DiCarlo, E. and Chang, V.K., (1995). Anatomy of the Achilles tendon and plantar fascia in relation to the calcaneus in various age groups. Foot $\&$ ankle international, 16(7), pp.418-421.

55) Song, B.-H., Choi, Y.-H., \& Cha, Y.-J. (2019). Comparison of Effects of Different Myofascial Meridians Methods on Pain and Postural Control of College Students with Forward Head Posture. Korean Society of Physical Medicine, 14(1), 15-23. https://doi.org/KSPM-14-015

56) Stecco, C., Pavan, P.G., Porzionato, A., Macchi, V., Lancerotto, L., Carniel, E.L., Natali, A.N. and De Caro, R. (2009). Mechanics of crural fascia: from anatomy to constitutive modelling. Surgical and Radiologic Anatomy, 31(7), pp.523-529

57) Stecco, C., Macchi, V., Porzionato, A., Morra, A., Parenti, A., Stecco, A., Delmas, V., and De Caro, R., (2010). The ankle retinacula: morphological evidence of the proprioceptive role of the fascial system. Cells Tissues Organs, 192(3), pp. 200-210

58) Stecco, A., Gesi, M., Stecco, C. and Stern, R., (2013). Fascial components of the myofascial pain syndrome. Current pain and headache reports, 17(8), p. 352

59) Still, A.T. (1910). Osteopathy research and practice. Kirksville (MO): Published by the author.

60) Sulowska, I., Mika, A., Oleksy, Ł., \& Stolarczyk, A. (2019). The Influence of Plantar Short Foot Muscle Exercises on the Lower Extremity Muscle Strength and Power in Proximal Segments of the Kinematic Chain in LongDistance Runners. BioMed research international, 2019, 6947273. doi:10.1155/2019/6947273

61) Tafazzoli, F. and Lamontagne, M., 1996. Mechanical behaviour of hamstring muscles in low-back pain patients and control subjects. Clinical Biomechanics, 11(1), pp.1624.

62) Tesarz, J., Hoheisel, U., Wiedenhöfer, B. and Mense, S. (2011). Sensory innervation of the thoracolumbar fascia in rats and humans. Neuroscience, 194, pp. 302-308

63) Tijs, C., Bernabei, M., van Dieën, J.H. and Maas, H. (2018). Myofascial loads can occur without fascicle length changes. Integrative and comparative biology, 58(2), pp.251-260.

64) Tomasek, J.J., Gabbiani, G., Hinz, B., Chaponnier, C., and Brown, R.A. (2002). Myofibroblasts and mechanoregulation of connective tissue remodelling. Nature reviews Molecular cell biology, 3(5), pp. 349-363

65) Tozzi, P. (2015). A unifying neuro-fasciagenic model of somatic dysfunction- underlying mechanisms and treatment-part I. Journal of bodywork and movement therapies, 19(2), pp. 310-326

66) Travell, J.G. and Simons, D.G. (1992). Myofascial pain and dysfunction, vols 1 and 2. Baltimore: Williams and Wilkins

67) van der Wal, J.(2009). The architecture of the connective tissue in the musculoskeletal system - an often overlooked functional parameter as to proprioception in the locomotor apparatus. International journal of therapeutic massage \& bodywork, 2(4), p.9

68) Vulfsons, S., Chervonenko, S., Haddad, M., Weisman, M. H., Lavi, N., \& Dar, G. (2018). Decreased amplitude of surface electromyo-graphic recordings of muscle activation along the posterior myofascial kinematic chain in subjects with chronic nonspecific low back pain compared to healthy subjects. Journal of back and musculoskeletal rehabilitation, , 1-9

69) Wang, J. (2019). Effects of Sling Forearm Plank Exercises on Superficial Back Line Muscle Tone and Stiffness. Journal of International Academy of Physical Therapy Research, 10(1), pp.1695-1699.

70) Weisman, M.H., Haddad, M., Lavi, N. and Vulfsons, S. (2014). Surface electromyographic recordings after passive and active motion along the posterior myofascial kinematic chain in healthy male subjects. Journal of bodywork and movement therapies, 18(3), pp. 452-461

71) Williams, W. and Selkow, N.M. (2019). Self-myofascial release of the superficial back line improves sit-and-reach distance. Journal of sport rehabilitation, 1(aop), pp.1-5.

72) Wilke, J., Krause, F., Vogt, L. and Banzer, W. (2016a). What is evidence-based about myofascial chains: a systematic review. Archives of physical medicine and rehabilitation, 97(3), pp. 454-461

73) Wilke, J., Niederer, D., Vogt, L., \&Banzer, W. (2016b). Remote effects of lower limb stretching: preliminary evidence for myofascial connectivity? Journal of sports sciences, 34(22), 2145-2148.

74) Wilke, J., Niederer, D., Vogt, L. and Banzer, W. (2016c). Impact of lower limb exercises on musculo-mechanical properties of the lumbar erector spinae. Journal of Bodywork and Movement Therapies, 20(1), pp. 154-155.

75) Wilke, J., Vogt, L., Niederer, D. and Banzer, W. (2017a). Is remote stretching based on myofascial chains as effective as local exercise? A randomised-controlled trial. Journal of sports sciences, 35(20), pp. 2021-2027

76) Wilke, J., Schleip, R., Yucesoy, C.A. and Banzer, W. (2017b). Not merely a protective packing organ? A review of fascia and its force transmission capacity. Journal of Applied Physiology, 124(1), pp.234-244.

77) Wilke, J., Kalo, K., Niederer, D., Vogt, L. and Banzer, W. (2019a). Gathering Hints for Myofascial Force Transmission Under In Vivo Conditions: Are Remote Exercise Effects Age Dependent?. Journal of sport rehabilitation, (00), pp.1-6.

78) Wilke, J. and Krause, F. (2019b). Myofascial chains of the upper limb: A systematic review of anatomical studies. Clinical Anatomy.

79) Woolf, A. D., \&Pfleger, B. (2003). Burden of major musculoskeletal conditions. Bulletin of the World Health Organization, 81(9), 646-56

80) Yucesoy, C.A. (2010). Epimuscular myofascial force transmission implies novel principles for muscular mechanics. Exercise and sport sciences reviews, 38(3), pp. 128-134

81) Zhang, X. (2019). Rehabilitation Training Analysis of Korfball Players Based on the Theory of Myofascial Chain. Caribbean Journal of Science, 52(4), pp.1722-1725 